\title{
Clinical Perspective on 2019 Novel Coronavirus Pneumonia: A Systematic Review of Published Case Reports
}

\author{
Rikinkumar S. Patel ${ }^{1}$, Neev Patel ${ }^{2}$, Mizba Baksh ${ }^{3}$, Annam Zaidi ${ }^{4}$, Jaiminkumar Patel ${ }^{5}$ \\ 1. Psychiatry, Griffin Memorial Hospital, Norman, USA 2. Medicine, Byramjee Jeejeebhoy Medical College, Ahmedabad, \\ IND 3. Internal Medicine, Dr. Nandamuri Taraka Rama Rao University of Health Sciences, Vijayawada, IND 4. Medicine, \\ Dow University of Health Sciences, Karachi, PAK 5. Internal Medicine, Albert Einstein College of Medicine, Bronx, USA
}

Corresponding author: Rikinkumar S. Patel, rpatel_09@arcadia.edu

\begin{abstract}
The ongoing pandemic of 2019 novel coronavirus (2019-nCoV), which originated from Wuhan, China, has led to 68,279 deaths due to 2019-nCoV pneumonia as of May 5, 2020. We conducted a systematic review and included 16 case reports to summarize the transmission and pathology of 2019-nCoV, and clinical presentation, laboratory and imaging findings, and treatment in 2019-nCoV pneumonia. The disease is mild in most people; in some, it may progress to severe pneumonia with acute respiratory distress syndrome (ARDS). Patients with mild illness usually recover at home, with supportive care and isolation in accordance with guidelines. Patients who have moderate to severe pneumonia are usually monitored in the hospital. Although there is no definitive treatment for 2019-nCoV pneumonia so far, some antiviral drugs have shown promising results. The use of lopinavir/ritonavir and remdesivir was associated with significant clinical improvement in severe pneumonia. Nonetheless, we need more randomized clinical trials (RCTs) and treatment guidelines for developing effective management of the 2019-nCoV and improve patient outcomes by reducing mortality in high-risk patients. We also need more clinical trials and management guidelines for the effective management of 2019-nCoV pneumonia.
\end{abstract}

Received 05/16/2020

Review began 05/29/2020 Review ended 05/30/2020 Published 06/07/2020

๑) Copyright 2020 Patel et al. This is an open access article distributed under the terms of the Creative Commons Attribution License CC-BY 4.0., which permits unrestricted use, distribution, and reproduction in any medium, provided the original author and source are credited.
Categories: Internal Medicine, Infectious Disease, Pulmonology

Keywords: multi-viral pneumonia, interstitial pneumonia, covid-2019, covid-19 pneumonia, novel corona virus, corona pandemic, ards

\section{Introduction And Background}

The ongoing outbreak of the 2019 novel coronavirus (2019-nCoV) has posed significant threats to international health and the economy [1]. In late December 2019, a cluster of patients were admitted to hospitals with an initial diagnosis of pneumonia of an unknown etiology. These patients were epidemiologically linked to the seafood and wet animal wholesale market in Wuhan, Hubei Province, China [2].

Analysis of the viral genome has revealed that the new coronavirus (CoV) is phylogenetically close to severe acute respiratory syndrome coronavirus (SARS-CoV), the causative agent of a viral outbreak in 2002. Thus, the new $\mathrm{CoV}$ has been named SARS-CoV type 2 by the International Committee on Taxonomy of Viruses (ICTV) and other virologists [3]. On February 11, 2020, the World Health Organization (WHO) DirectorGeneral announced that the disease caused by this new CoV was called as coronavirus disease 2019 (COVID19).

This new virus seems to be very contagious and has quickly spread globally. On March 11, 2020, as the number of 2019-nCoV cases outside China has increased 13 times and the number of countries involved has tripled with more than 118,000 cases in 114 countries and over 4,000 deaths, WHO declared the 2019-nCoV a pandemic [4]. As of May 5, 2020, there is around 1,171,510 total number of both confirmed and probable 2019-nCoV cases in the United States (US), the highest in the world, and the total number of deaths is approximately 68,279 , the majority caused by pneumonia [5].

Person-to-person transmission of SARS-CoV-2 occurs primarily through close contact with an infected person, mainly via respiratory droplets and after touching contaminated objects. Additional routes of transmission are currently under investigation, including fecal viral shedding [6]. The most common presenting symptoms are fever, cough, sore throat, breathlessness, fatigue, and malaise. The disease is mild in most people; in some (usually the elderly and those with comorbidities), it may progress to pneumonia, acute respiratory distress syndrome (ARDS), and multiorgan dysfunction [7].

In this systematic review based on findings of previously published case reports on pneumonia in 2019nCoV, we have broadly summarized the transmission and pathology of 2019-nCoV, and demographics, clinical presentation, laboratory, and chest imaging findings, along with treatment and outcomes in 2019- 


\section{Cureus}

nCoV pneumonia patients.

\section{Review}

\section{Study search strategy and selection}

The MEDLINE database from the National Library of Medicine (NLM) was used to identify case reports published in English from December 1, 2019 to April 6, 2020. The search strings in title/abstract were 'COVID-19' or 'coronavirus' or '2019-nCoV' and 'pneumonia' that yielded 17 articles. All searches and screening were done independently by two authors (R Patel, J Patel) using the preferred reporting items for systematic reviews and meta-analyses statement (PRISMA) recommendations. The titles and abstracts were screened, based on the purpose of our review, and resulted in the exclusion of one article. A total of 16 case report articles met the criteria for our systematic review and were included as shown in Figure 1.
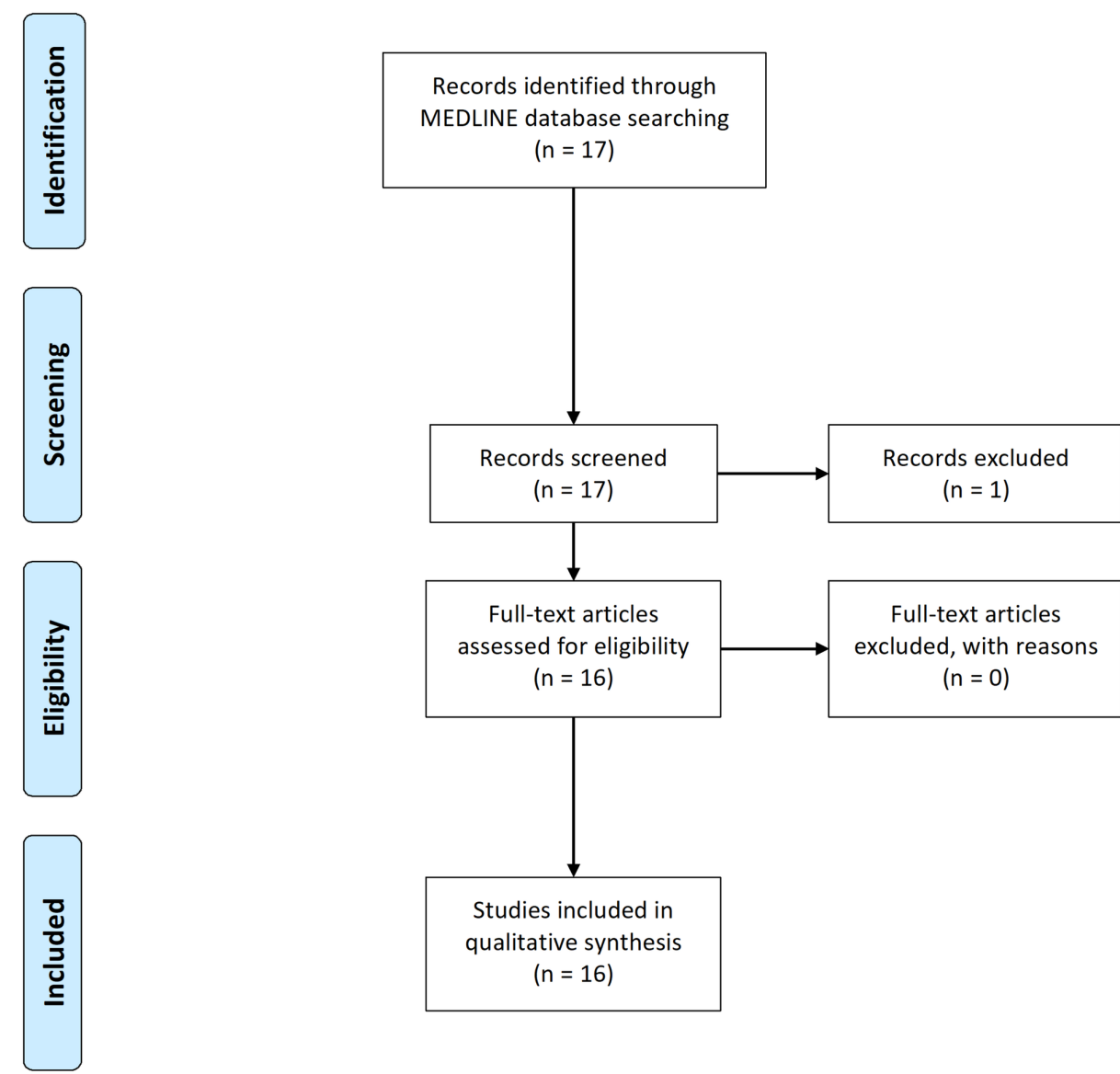

FIGURE 1: Results of systematic review

\section{Pathology and transmission}

Cases of COVID-2019 pneumonia are caused by a CoV called SARS-CoV-2, which is a novel type of beta-CoV. The 2019-nCoV is the seventh member of the $\mathrm{CoV}$ family that includes Middle East respiratory syndrome $\mathrm{CoV}$ (MERS-CoV) and SARS-CoV [8]. Most early patients had a history of exposure to the south China seafood market in Wuhan. The source of infection is proposed to be the Chinese rufous horseshoe bat, yet the exact source of the virus is still unknown [8-10].

One study of two patients highlights the use of a low-input metagenomic next-generation sequencing (mNGS) approach on ribonucleic acid (RNA) extracted from bronchoalveolar lavage fluid. It rapidly identifies the $2019-\mathrm{nCoV}$, which was the sole pathogen in the sample, with a very high abundance level (1.5\% and $0.62 \%$ of total RNA sequenced). Based on the results of genome mapping, data revealed extremely active $\mathrm{CoV}$ replication in the lungs of patients [10].

Transmission of 2019-nCoV is mainly via droplets, but it can also be through contact with one another (within six feet distance). In an analysis of 75,465 2019-nCoV cases in China, the airborne transmission was not reported [11]. The incubation period of 2019-nCoV is generally no longer than 14 days, with a median time of four to five days from exposure to onset of symptoms, and the patient is infective during the 
incubation period [8].

Elderly patients or those with underlying diseases are more seriously affected during the 2019-nCoV pandemic, whereas low infection rate and mild symptoms have been noted in the pediatric population, which could potentially be explained by greater innate immunity early in life and less exposure compared to adults [12]. Elderly 2019-nCoV infected patients are more likely to have bacterial infections, which can be a contributing factor to a higher case fatality rate in the elderly [13]. Asymptomatic individuals may transmit 2019-nCoV to other people, but it remains to be determined how common are such transmissions. Transmission dynamics and the full spectrum of clinical illness are yet to be fully understood [14].

\section{Pathophysiology}

2019-nCoV is comprised of a single-stranded RNA structure that belongs to the Coronavirinae subfamily. Sequence analysis of SARS-CoV-2 has shown a structure typical to that of other CoV and its genome has been likened to a previously identified CoV strain that caused the SARS outbreak in 2003 [15]. 2019-nCoV shared 98.7\% nucleotide identity to bat CoV strain BtCoV/4991 and 87.9\% nucleotide identity to bat-SLCoVZC45 and bat-SL-CoVZXC21 strains, indicating that it was quite divergent from the currently known human CoV, including SARS-CoV [10].

SARS-CoV-2, a single-stranded RNA-enveloped virus, targets cells through the viral structural spike (S) protein that binds to the angiotensin-converting enzyme 2 (ACE2) receptor. Following receptor binding, the virus particle uses host cell receptors and endosomes to enter cells. A host type 2 transmembrane serine protease (TMPRSS2) facilitates cell entry via the S protein [16]. ACE2 is predominantly expressed by epithelial cells of the lung, intestine, kidney, heart, and blood vessels. A recent study by Liu et al. showed that serum angiotensin II levels in patients with 2019-nCoV pneumonia was significantly higher compared with healthy individuals and were linearly associated with viral load and lung injury [13]. Based on this, it can be postulated that SARS-CoV-2 binding to ACE2 may attenuate residual ACE2 activity, skewing the ACE/ACE2 balance to a state of heightened angiotensin II activity leading to pulmonary vasoconstriction and inflammatory and oxidative organ damage, which increases the risk for acute lung injury [17].

Microscopic findings included diffuse alveolar damage with exudates [18]. The inflammation was predominantly lymphocytic, and multinucleated giant cells were seen alongside large atypical pneumocytes, although no definitive viral inclusions were noted [19].

\section{Demographics}

This study included published 16 case reports $(\mathrm{N}=22)$, patients were from China, Korea, Taiwan, Canada, and the US. All patients with 2019-nCoV were studied for the development of pneumonia. Patients were males $(\mathrm{N}=13)$ and females $(\mathrm{N}=9)$ with an age range from 10 to 75 years.

\section{Clinical presentation}

The most common clinical presentation of 2019-nCoV infection includes fever, fatigue, and dry cough; some patients present with nasal congestion, runny nose, myalgia, and chills. Headache, confusion, chest tightness, pleuritic chest discomfort, rhinorrhea, sore throat, hemoptysis, vomiting, abdominal discomfort, constipation, and diarrhea have been reported but are less common [9,10,20-22]. Some patients with 2019$\mathrm{nCoV}$ have experienced gastrointestinal symptoms, such as diarrhea and nausea, prior to developing fever and lower respiratory tract signs and symptoms [14]. In one case report, the patient complained of psychiatric symptoms, such as depression, insomnia, and suicidal thoughts after isolation, due to stress regarding people's reactions from the media reports about the 2019-nCoV patients [23].

Most patients came to visit the outpatient clinic and/or emergency department (ED) after three to five days of onset of symptoms. In some patients' symptoms gradually worsened with exertional dyspnea, high-grade fever, and type I respiratory failure [10,20,24]. In severe cases, dyspnea usually occurs one week after the onset of symptoms, and some patients can rapidly progress in 8-12 days to ARDS. The disease course of 2019-nCoV pneumonia was similar in most cases with the exception of two patients with severe 2019-nCoV pneumonia who developed complications such as ARDS, septic shock, and multiple organ dysfunction syndromes (MODS) requiring non-invasive ventilation [22,25]. There was one case from Korea of a 10-yearold girl, who was in close contact with her uncle and mother who were confirmed to have 2019-nCoV. She presented with mild pneumonia on chest CT and recovered completely by only placing her in a negative isolation unit [12].

In patients with a history of fever, cough, or contact with the epidemic area combined with significant chest CT findings, timely detection of the $2019-\mathrm{nCoV}$ is required to ensure early diagnosis, isolation, and treatment [8]. During the early stages of infection, one cannot predict progression from upper respiratory infection to severe 2019-nCoV pneumonia. Considering this, it is safer to do a 2019-nCoV screening test for all symptomatic patients with epidemiological risk than to wait until full-blown pneumonia develops [9].

\section{Imaging results and lab findings}


Chest CT scan is a highly sensitive diagnostic tool to detect pneumonia because the chest x-ray (CXR) could be normal in those patients with mild or no symptoms. The most common finding on chest CT was groundglass opacities, involving bilateral lungs with peripheral distribution noted in most patients; interlobular septal thickening and consolidation are common associated findings. As 2019-nCoV pneumonia progresses, an increase in size and density of the ground-glass opacities or crazy-paving patterns were reported [24]. One case demonstrated that the ground-glass opacities and consolidations will decrease in size as a patient recovers, though the fibrotic changes may remain as a sequela after recovery [20]. Subpleural opacities were also observable with lesions limited to lower lobe lung $[8,9,12,26-28]$. With a high-resolution chest CT, it will be easier to find ground-glass opacities in the early stage [26].

A few cases reported abnormalities on chest CT when CXR was normal, which led to an early diagnosis $[9,23,26]$. However, the chest CT imaging pattern is non-specific and overlaps with other infections, making the diagnostic value of chest CT imaging for 2019-nCoV low and dependent upon interpretations from individual radiologists [29]. Chest CT should not be used as a first-line test for screening or diagnosis and should be reserved for hospitalized, symptomatic patients with specific clinical indications. Given the variability in chest imaging findings, chest radiograph or chest $\mathrm{CT}$ alone is not recommended for the diagnosis of 2019-nCoV [22]. Confirmation with the viral test is required, even if radiologic findings are suggestive of 2019-nCoV on CXR or chest CT [30].

In throat-swab specimens from the upper respiratory tract that were obtained from all patients, 2019-nCoV was confirmed by real-time reverse transcriptase-polymerase chain reaction (RT-PCR) [10]. Detection of SARS-CoV-2 RNA in the blood may be a marker of severe illness [31]. SARS-CoV-2 RNA has also been detected in stool samples. Test for respiratory panel (including respiratory syncytial virus, parainfluenza virus, rhinovirus, adenovirus, metapneumovirus, Mycoplasma pneumoniae, Chlamydia pneumoniae, Legionella pneumophila, and CoV strains like HKU1, NL63, 229E, OC43) and influenza A and B were all negative $[8,10,14,21,26]$.

Lymphopenia is the most common lab finding in 2019-nCoV patients. In one case, a detailed laboratory investigation revealed lymphopenia and elevated aspartate aminotransferase (AST), alanine aminotransferase (ALT), c-reactive protein (CRP), and lactate dehydrogenase (LDH), which may be associated with greater illness severity $[20,22]$. Laboratory findings in one of the patients showed that there were elevated blood levels of CRP, erythrocyte sedimentation rate (ESR), and D-dimer level [27]. Some other findings on laboratory results were elevated creatine kinase (CK), elevated alkaline phosphatase (ALP), increased level of hematocrit, increased neutrophil count, decreased lymphocyte count, increased lymphokine, and thrombocytopenia $[14,21,24,26]$.

\section{Treatment and outcomes}

The milder spectrum of pneumonia caused by 2019-nCoV suggests that the identification of individuals who could be managed by being quarantined at home, rather than in a hospital, might be an important strategy for containing the 2019-nCoV pandemic [21]. Patients who have mild illness usually recover at home, with supportive care and isolation in accordance with guidelines. Patients who have moderate or severe diseases are usually monitored in the hospital [32]. Treatment modalities for all the patients included isolation in a negative pressure room and supportive care. Such isolation rooms can control airflow to prevent viruses from escaping into the rest of the hospital. Preferred empirical antibiotics were ceftriaxone, amoxicillin/clavulanate, and tabaxin, meropenem and linezolid, and antiviral medications included oseltamivir and ganciclovir, and interferon inhalation [20,26,27,33,34].

One of the cases that was tested positive for 2019-nCoV was isolated in negative pressure room and treated with antiviral medication: lopinavir (LPV): $200 \mathrm{mg} / \mathrm{capsule}$, ritonavir (RTV) $50 \mathrm{mg} / \mathrm{capsule}$ twice a day (BID). Interestingly, the next day CoV load monitored by quantitative real-time RT-PCR decreased significantly to no detectable titers [23]. One study found that four 2019-nCoV positive patients were administered antiviral treatment, including LPV/RTV, arbidol, and Shufeng Jiedu Capsule (SFJDC, a traditional Chinese medicine) and supplemental oxygen. After the treatment, three patients gained significant improvement in pneumonia symptoms, and routine blood analysis revealed that leukocytes and lymphocytes were increased indicating restoration of the immune system, and they were confirmed 2019-nCoV negative and discharged. Only one of the four patients developed severe pneumonia and received immunoglobulin therapy with intubated ventilator-assisted breathing therapy due to refractory low blood oxygen pressure, and this patient also showed signs of clinical improvement [22].

One of the cases received supportive treatment initially and later on received vancomycin and cefepime. This patient developed severe pneumonia with high 2019-nCoV viral load, and so received antiviral therapy with intravenous remdesivir (a novel nucleotide analog prodrug in development) on day 7 , and the next day, patient's clinical condition significantly improved [14]. When LPV/RTV was used in high-risk groups of 2019-nCoV pneumonia, it showed reduced viral loads and improvement in clinical symptoms during the treatment [23]. LPV/RTV regimen has shown substantial clinical benefit in China and is currently recommended along with SFJDC by National Health Commission of the People's Republic of China [35]. However, observational studies done during an epidemic often do not have concurrent controls, have a 


\section{Cureus}

significant risk of bias, and use surrogate outcomes like viral clearance rather than patient-important outcomes [36]. Most of the patients in our systematic review demonstrated a good prognosis with no complications. However, two patients had developed ARDS and MODS. All the patients, at the end of hospitalization, were cured and discharged in stable condition.

Currently, the Centers for Disease Control and Prevention (CDC) panel recommends against the use of combination of LPV/RTV or other human immunodeficiency virus (HIV) protease inhibitors for the treatment of 2019-nCoV pneumonia, except in the context of a clinical trial [37]. On the contrary, remdesivir has been recently recognized as a promising antiviral drug against a wide array of RNA viruses (including SARS/MERS-CoV5) infection in cultured cells, mice, and non-human primate models [38]. In vitro studies showed that remdesivir can inhibit SARS-CoV and MERS-CoV replication, and in an in vitro test utilizing epithelial cell cultures of a primary human airway, remdesivir was effective against bat-CoV, prepandemic bat-CoV, and circulating contemporary human-CoV in primary human lung cells. Remdesivir improved pulmonary function, reduced lung viral loads, and ameliorated severe lung pathology [39]. In contrast, prophylactic LPV/RTV-interferon- $\beta$ (IFN- $\beta$ ) reduced viral loads and did not impact other disease parameters, and therapeutic LPV/RTV-IFN- $\beta$ improved pulmonary function but did not reduce virus replication or severe lung pathology. Overall, these results indicated that remdesivir showed more potential than LPV/RTV-IFN- $\beta$ for treating MERS-CoV infections [40]. Also, a systematic review on acute respiratory distress patients, who were positive for 2019-nCoV, was managed with LPV/RTV with or without oseltamivir, out of which the majority of them showed significant improvement [41].

Patients with advanced 2019-nCoV pneumonia who received remdesivir recovered faster than similar patients who received a placebo, according to a preliminary data analysis from the first randomized controlled trial (RCT) involving 1,063 patients in the US [42]. Recently, the US food and drug administration (FDA) issued an emergency use authorization (EUA) allowing for remdesivir to be distributed in the US and administered by healthcare providers, as appropriate, to treat suspected or confirmed 2019-nCoV positive adults and children with severe disease [43].

An overview of the included case reports is shown in Table 1.

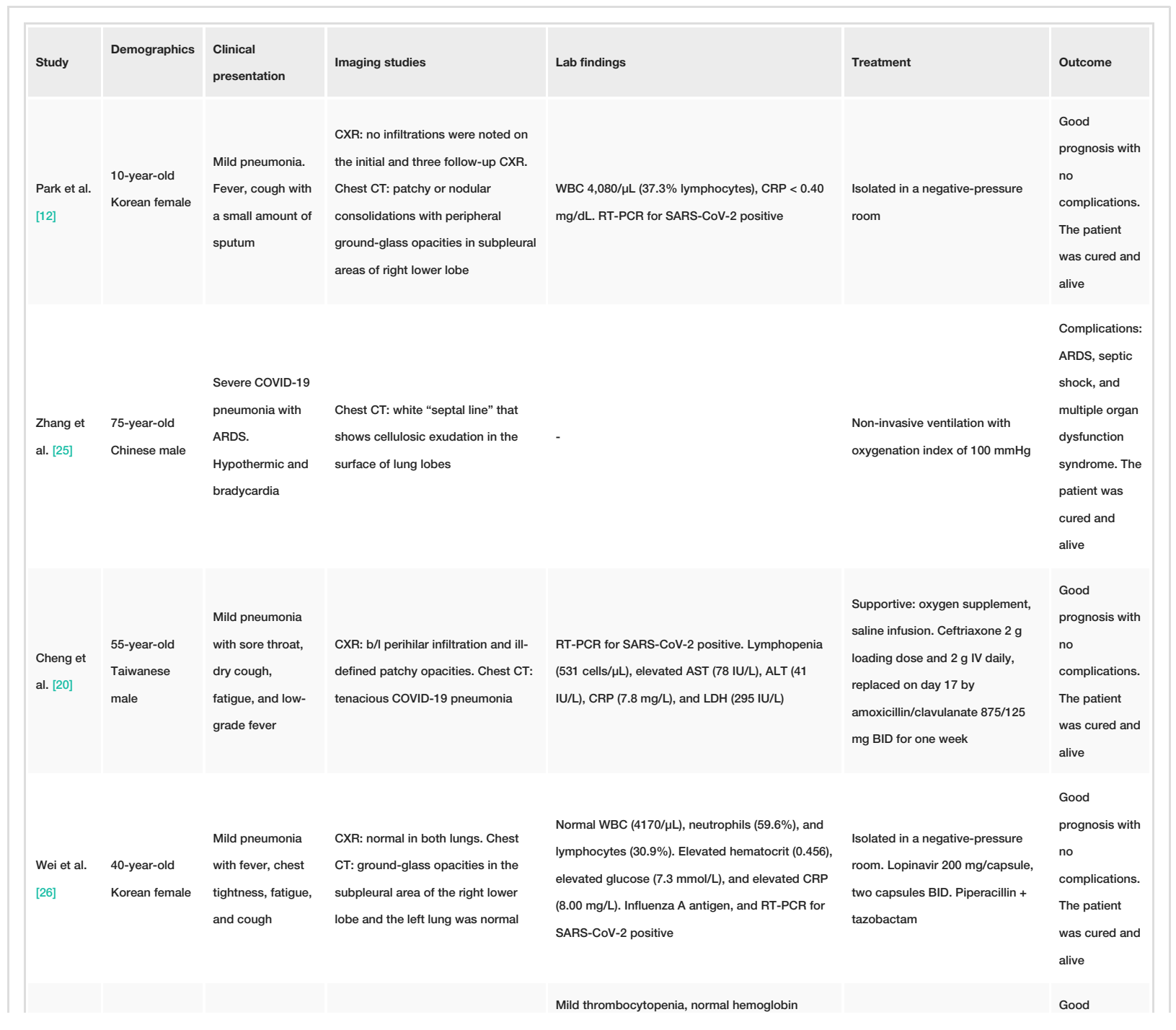




\section{Cureus}

\begin{tabular}{|c|c|c|c|c|c|c|}
\hline et al. [21] & $\begin{array}{l}56 \text {-year-old } \\
\text { male }\end{array}$ & $\begin{array}{l}\text { Mild pneumonia } \\
\text { with fever, non- } \\
\text { productive cough, } \\
\text { mild hemoptysis, } \\
\text { and significant } \\
\text { rhinorrhea }\end{array}$ & $\begin{array}{l}\text { pXribronchovascular, ill-defined } \\
\text { opacities in all lung zones }\end{array}$ & $\begin{array}{l}\text { concentration, and normal WBC. ALT } 29 \mathrm{IU} / \mathrm{L} \text { and } \\
\text { lactate concentration } 1 \cdot 1 \mathrm{mmol} / \mathrm{L} \text {. Influenza virus } \\
\text { A and influenza virus B, parainfluenza virus, } \\
\text { respiratory syncytial virus, adenovirus, and human } \\
\text { metapneumovirus: negative. RT-PCR for SARS- } \\
\text { CoV-2 positive }\end{array}$ & $\begin{array}{l}\text { Isolated in a negative-pressure } \\
\text { room }\end{array}$ & $\begin{array}{l}\text { prognosis with } \\
\text { no } \\
\text { complications. } \\
\text { The patient } \\
\text { was cured and } \\
\text { alive }\end{array}$ \\
\hline $\begin{array}{l}\text { Lim et al. } \\
\text { [23] }\end{array}$ & $\begin{array}{l}\text { 54-year-old } \\
\text { Korean male }\end{array}$ & $\begin{array}{l}\text { Mild pneumonia } \\
\text { with chills, muscle } \\
\text { pain, fever, and } \\
\text { dry cough }\end{array}$ & $\begin{array}{l}\text { CXR: no haziness. Chest CT: Small } \\
\text { consolidation in the right upper lobe } \\
\text { and ground-glass opacities in both } \\
\text { lower lobes }\end{array}$ & $\begin{array}{l}\text { Leptospira, Hantaan virus, tsutsugamushi, } \\
\text { malaria, Mycobacterium tuberculosis, HIV, and } \\
\text { VDRL test: negative. RT-PCR for SARS-CoV-2 } \\
\text { positive }\end{array}$ & $\begin{array}{l}\text { Isolated in a negative-pressure } \\
\text { room. Lopinavir } 200 \mathrm{mg} / \text { ritonavir } \\
50 \mathrm{mg} \text {, two tablets per oral }\end{array}$ & $\begin{array}{l}\text { Good } \\
\text { prognosis with } \\
\text { no } \\
\text { complications. } \\
\text { The patient } \\
\text { was cured and } \\
\text { alive }\end{array}$ \\
\hline $\begin{array}{l}\text { Duan and } \\
\text { Qin [27] }\end{array}$ & $\begin{array}{l}\text { 46-year-old } \\
\text { Chinese } \\
\text { female }\end{array}$ & $\begin{array}{l}\text { Mild pneumonia } \\
\text { with fever without } \\
\text { chills and rigor, } \\
\text { nasal discharge, } \\
\text { cough, and } \\
\text { myalgia }\end{array}$ & $\begin{array}{l}\text { ground-glass opacities in the } \\
\text { lobes without sparing of subpleural } \\
\text { regions }\end{array}$ & $\begin{array}{l}\text { lymphocytes). Elevated blood levels for CRP ( } 6.4 \\
\mathrm{mg} / \mathrm{L} \text { ), ESR ( } 27 \mathrm{~mm} / \mathrm{h} \text { ), and D-dimer ( } 566 \mathrm{ng} / \mathrm{mL}) \text {. } \\
\text { RT-PCR for SARS-CoV-2 positive }\end{array}$ & $\begin{array}{l}\text { Isolated in a negative-pressure } \\
\text { room. Interferon inhalation }\end{array}$ & $\begin{array}{l}\text { Good } \\
\text { prognosis with } \\
\text { no } \\
\text { complications. } \\
\text { The patient } \\
\text { was cured and } \\
\text { alive }\end{array}$ \\
\hline \multirow{4}{*}{$\begin{array}{l}\text { Wang et } \\
\text { al. [22] }\end{array}$} & $\begin{array}{l}\text { 32-year-old } \\
\text { Chinese male }\end{array}$ & $\begin{array}{l}\text { Mild pneumonia } \\
\text { with fever, fatigue. } \\
\text { dizziness, and } \\
\text { constipation }\end{array}$ & $\begin{array}{l}\text { Chest CT: ground-glass opacities } \\
\text { and consolidation, b/l pneumonia }\end{array}$ & $\begin{array}{l}57.2 \% \text { neutrophils). RT-PCR for SARS-CoV-2 } \\
\text { positive }\end{array}$ & $\begin{array}{l}\text { Oxygen therapy and antibiotics. } \\
\text { Lopinavir/ritonavir/arbidol/SFJDC }\end{array}$ & $\begin{array}{l}\text { Good } \\
\text { prognosis with } \\
\text { no } \\
\text { complications. } \\
\text { The patient } \\
\text { was cured and } \\
\text { alive }\end{array}$ \\
\hline & $\begin{array}{l}\text { 19-year-old } \\
\text { Chinese male }\end{array}$ & $\begin{array}{l}\text { Mild pneumonia } \\
\text { with fever, fatigue, } \\
\text { cough, nasal } \\
\text { congestion, } \\
\text { rhinorrhea }\end{array}$ & $\begin{array}{l}\text { Chest CT: ground-glass opacities } \\
\text { and consolidation, unilateral } \\
\text { pneumonia }\end{array}$ & $\begin{array}{l}\text { Normal WBC 6,480/pL (30.6\% lymphocytes, } 57 \% \\
\text { neutrophils). RT-PCR for SARS-CoV-2 positive }\end{array}$ & $\begin{array}{l}\text { Oxygen therapy and antibiotics. } \\
\text { Lopinavir/ritonavir/arbidol/SFJDC }\end{array}$ & $\begin{array}{l}\text { Good } \\
\text { prognosis with } \\
\text { no } \\
\text { complications. } \\
\text { The patient } \\
\text { was cured and } \\
\text { alive }\end{array}$ \\
\hline & $\begin{array}{l}\text { 63-year-old } \\
\text { Chinese male }\end{array}$ & $\begin{array}{l}\text { Severe pneumonia } \\
\text { with fever and } \\
\text { cough }\end{array}$ & $\begin{array}{l}\text { Chest CT: ground-glass opacities } \\
\text { and consolidation, unilateral } \\
\text { pneumonia }\end{array}$ & $\begin{array}{l}\text { Normal WBC } 4.400 / \mu L \text { ( } 24.5 \% \text { lymphocytes, } 50 \% \\
\text { neutrophils). RT-PCR for SARS-CoV-2 positive }\end{array}$ & $\begin{array}{l}\text { Oxygen therapy and antibiotics. } \\
\text { Lopinavir/ritonavir/arbidol/SFJDC }\end{array}$ & $\begin{array}{l}\text { Good } \\
\text { prognosis with } \\
\text { no } \\
\text { complications. } \\
\text { The patient } \\
\text { was cured and } \\
\text { alive }\end{array}$ \\
\hline & $\begin{array}{l}\text { 63-year-old } \\
\text { Chinese } \\
\text { female }\end{array}$ & $\begin{array}{l}\text { Severe pneumonia } \\
\text { with fever, cough, } \\
\text { dizziness, and } \\
\text { constipation }\end{array}$ & $\begin{array}{l}\text { Chest CT: ground-glass opacities } \\
\text { and consolidation, b/l pneumonia }\end{array}$ & $\begin{array}{l}\text { Normal WBC 6,840/pL (low lymphocytes } 6.1 \% \\
\text {,high neutrophils 93\%). RT-PCR for SARS-CoV-2 } \\
\text { positive }\end{array}$ & $\begin{array}{l}\text { Oxygen therapy mechanical } \\
\text { ventilation. Antibiotic treatment. } \\
\text { Lopinavir/ritonavir/arbidol/SFJDC. } \\
\text { IV IG therapy }\end{array}$ & $\begin{array}{l}\text { Complication: } \\
\text { hypoxia. The } \\
\text { patient was } \\
\text { cured and } \\
\text { alive }\end{array}$ \\
\hline $\begin{array}{l}\text { Shi et al. } \\
\text { [33] }\end{array}$ & $\begin{array}{l}\text { 42-year-old } \\
\text { Chinese male }\end{array}$ & $\begin{array}{l}\text { Mild pneumonia } \\
\text { with high-grade } \\
\text { fever }\left(39.6^{\circ} \mathrm{C}\right) \\
\text { cough, and fatigue }\end{array}$ & $\begin{array}{l}\text { CXR: opacities in the left lower and } \\
\text { right upper lobes. Chest CT: } \\
\text { multifocal b/l ground-glass opacities }\end{array}$ & $\begin{array}{l}\text { Low WBC } 2,880 / \mu \mathrm{L} \text { ( } 56.6 \% \text { neutrophils, } 32.1 \% \\
\text { lymphocytes, and } 10.2 \% \text { monocytes). Elevated } \\
\text { CRP } 158.95 \mathrm{mg} / \mathrm{L} \text {, ESR ( } 38 \mathrm{~mm} / \mathrm{h} \text { ), and serum } \\
\text { amyloid A protein ( } 607.1 \mathrm{mg} / \mathrm{L}) \text {. Elevated AST ( } 53 \\
\text { IU/L), ALT (60 IU/L). RT-PCR for SARS-CoV-2 } \\
\text { positive }\end{array}$ & $\begin{array}{l}\text { Supportive care. Antivirals: } \\
\text { ganciclovir, oseltamivir. } \\
\text { Antibiotics: meropenem, linezolid }\end{array}$ & $\begin{array}{l}\text { Good } \\
\text { prognosis with } \\
\text { no } \\
\text { complications. } \\
\text { The patient } \\
\text { was cured and } \\
\text { alive }\end{array}$ \\
\hline & $\begin{array}{l}\text { 45-year-old } \\
\text { Chinese } \\
\text { female }\end{array}$ & $\begin{array}{l}\text { Mild pneumonia } \\
\text { with fever and } \\
\text { cough }\end{array}$ & $\begin{array}{l}\text { Chest CT: multiple b/l areas of } \\
\text { peripheral consolidation. There was } \\
\text { interlobular septal thickening with a } \\
\text { crazy-paving appearance and } \\
\text { bronchiectasis. The adjacent pleura } \\
\text { was thickened, without mediastinal } \\
\text { lymphadenopathy or pleural fluid }\end{array}$ & $\begin{array}{l}\text { Increased neutrophil ratio }(81.2 \%) \text {, decreased } \\
\text { lymphocyte ratio }(12.8 \%) \text {, Increased ESR ( } 24 \\
\mathrm{~mm} / \mathrm{h}) \text {, normal D-dimer concentration, and } \\
\text { increased lymphokine interleukin } 6(27.47 \mathrm{pg} / \mathrm{mL}) \text {. } \\
\text { RT-PCR for SARS-CoV-2 positive }\end{array}$ & $\begin{array}{l}\text { Antiviral and symptomatic } \\
\text { treatment }\end{array}$ & $\begin{array}{l}\text { Good } \\
\text { prognosis with } \\
\text { no } \\
\text { complications. } \\
\text { The patient } \\
\text { was cured and } \\
\text { alive }\end{array}$ \\
\hline
\end{tabular}




\section{Cureus}

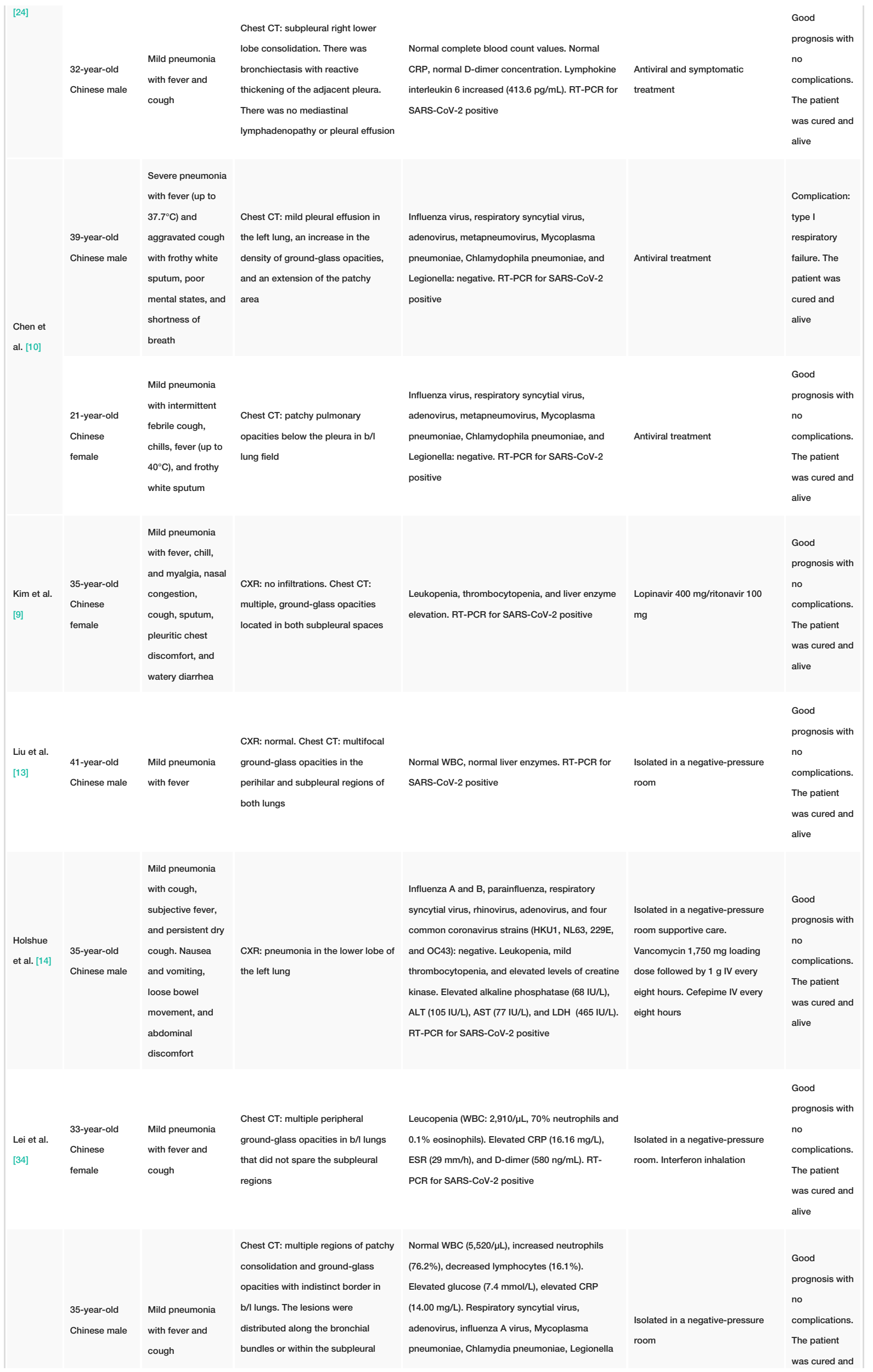




\section{Cureus}

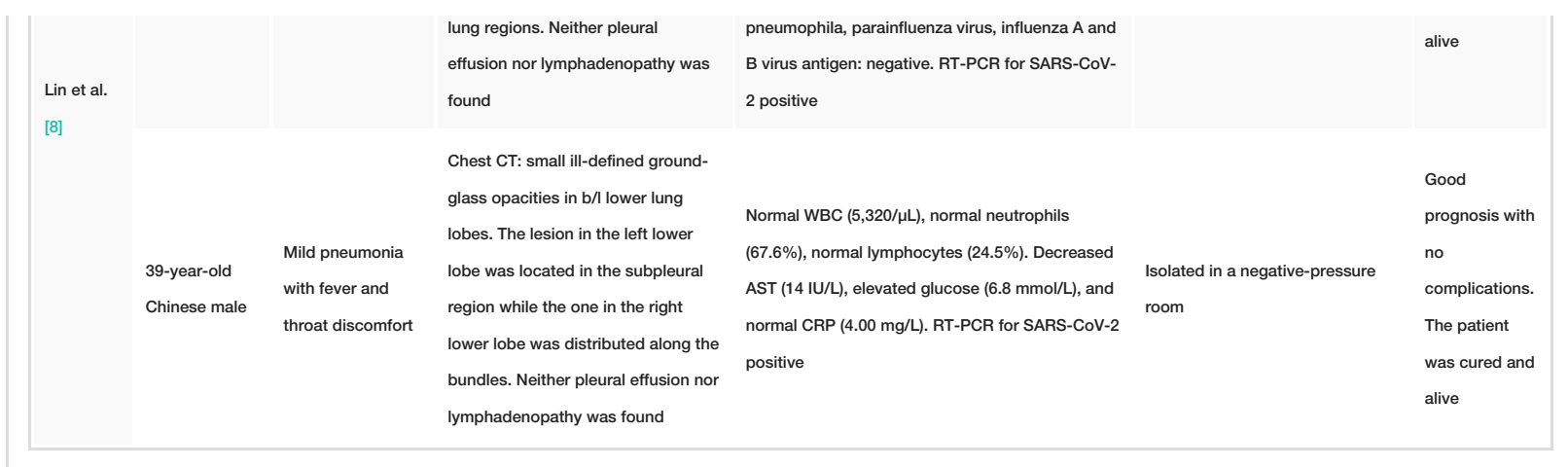

\section{TABLE 1: Summary of included case reports of 2019 novel coronavirus pneumonia}

COVID-19: coronavirus disease 2019; b/l: bilateral; CXR: chest x-ray; WBC: white blood cell; BID: twice daily; IV: intravenous; CRP: C-reactive protein; RT-PCR: real-time reverse transcription-polymerase chain reaction; SARS-CoV-2: severe acute respiratory syndrome coronavirus 2; AST: aspartate aminotransferase; ALT: alanine aminotransferase; LDH: lactate dehydrogenase; VDRL: venereal disease research laboratory; ESR: erythrocyte sedimentation rate; ARDS: acute respiratory distress syndrome; SFJDC: Shufeng Jiedu Capsule; IV IG: intravenous immunoglobulin; HIV: human immunodeficiency virus; IU/L: international units per liter; $\mathrm{pg} / \mathrm{mL}$ : picogram per milliliter; $\mathrm{mmol} / \mathrm{L}$ : millimoles per liter.

\section{Conclusions}

The results of our systematic review of published case reports of pneumonia in 2019-nCoV positive patients will help healthcare professionals to understand the pathophysiology and transmission, clinical presentation, imaging and laboratory findings, and treatment. Most patients presented with fever, fatigue, and dry cough; some present with nasal congestion, runny nose, myalgia, and chills. The most common finding on chest CT was ground-glass opacities, involving bilateral lungs with the peripheral distribution. Lymphopenia was the most common lab finding, and along with other inflammatory markers in patients with greater illness severity. The use of LPV/RTV and remdesivir was associated with significant clinical improvement in severe pneumonia. Nonetheless, we need more RCTs and treatment guidelines for developing effective management of the $2019-\mathrm{nCoV}$ and improve patient outcomes by reducing mortality in high-risk patients.

\section{Additional Information}

\section{Disclosures}

Conflicts of interest: In compliance with the ICMJE uniform disclosure form, all authors declare the following: Payment/services info: All authors have declared that no financial support was received from any organization for the submitted work. Financial relationships: All authors have declared that they have no financial relationships at present or within the previous three years with any organizations that might have an interest in the submitted work. Other relationships: All authors have declared that there are no other relationships or activities that could appear to have influenced the submitted work.

\section{References}

1. Hu Y, Sun J, Dai Z, et al.: Prevalence and severity of corona virus disease 2019 (COVID-19): a systematic review and meta-analysis. J Clin Virol. 2020, 127:104371. 10.1016/j.jcv.2020.104371

2. Rothan HA, Byrareddy SN: The epidemiology and pathogenesis of coronavirus disease (COVID-19) outbreak . J Autoimmun. 2020, 109:102433. 10.1016/.j.jaut.2020.102433

3. Ahn DG, Shin HJ, Kim MH, et al.: Current status of epidemiology, diagnosis, therapeutics, and vaccines for novel coronavirus disease 2019 (COVID-19). J Microbiol Biotechnol. 2020, 30:313-324. 10.4014/jmb.2003.03011

4. Spinelli A, Pellino G: COVID-19 pandemic: perspectives on an unfolding crisis . Br J Surg. 2020, 107:785-787. $10.1002 /$ bjs. 11627

5. Coronavirus disease 2019 (COVID-19). Cases in the U.S . (2020). Accessed: May 5, 2020 https://www.cdc.gov/coronavirus/2019-ncov/cases-updates/cases-in-us.html.

6. Castagnoli R, Votto M, Licari A, et al.: Severe acute respiratory syndrome coronavirus 2 (SARS-Cov-2) infection in children and adolescents: a systematic review (Epub ahead of print). JAMA Pediatr. 2020, 10.1001/jamapediatrics.2020.1467

7. Singhal T: A review of coronavirus disease-2019 (COVID-19). Indian J Pediatr. 2020, 87:281-286. 10.1007/s12098-020-03263-6

8. Lin X, Gong Z, Xiao Z, Xiong J, Fan B, Liu J: Novel coronavirus pneumonia outbreak in 2019: computed tomographic findings in two cases. Korean J Radiol. 2020, 21:365-368. 10.3348/kjr.2020.0078

9. Kim JY, Choe PG, Oh Y, et al.: The first case of 2019 novel coronavirus pneumonia imported into Korea from Wuhan, China: implication for infection prevention and control measures. J Korean Med Sci. 2020, 35:e61. 10.3346/jkms.2020.35.e61

10. Chen L, Liu W, Zhang $\mathrm{Q}$, et al.: RNA based mNGS approach identifies a novel human coronavirus from two 
individual pneumonia cases in 2019 Wuhan outbreak. Emerg Microbes Infect. 2020, 9:313-319. 10.1080/22221751.2020.1725399

11. Ong SWX, Tan YK, Chia PY, et al.: Air, surface environmental, and personal protective equipment contamination by severe acute respiratory syndrome coronavirus 2 (SARS-CoV-2) from a symptomatic patient. JAMA. 2020, 323:1610-1612. 10.1001/jama.2020.3227

12. Park JY, Han MS, Park KU, Kim JY, Choi EH: First pediatric case of coronavirus disease 2019 in Korea . J Korean Med Sci. 2020, 35:e124. 10.3346/jkms.2020.35.e124

13. Liu Y, Yang Y, Zhang C, et al.: Clinical and biochemical indexes from 2019-nCoV infected patients linked to viral loads and lung injury. Sci China Life Sci. 2020, 63:364-374. 10.1007/s11427-020-1643-8

14. Holshue ML, DeBolt C, Lindquist S, et al.: First case of 2019 novel coronavirus in the United States . N Engl J Med. 2020, 382:929-936. 10.1056/NEJMoa2001191

15. Sohrabi C, Alsafi Z, O'Neill N, et al.: World Health Organization declares global emergency: a review of the 2019 novel coronavirus (COVID-19). Int J Surg. 2020, 76:71-76. 10.1016/j.ijsu.2020.02.034

16. Sanders JM, Monogue ML, Jodlowski TZ, Cutrell JB: Pharmacologic treatments for coronavirus disease 2019 (COVID-19): a review. JAMA. 2020, 323:1824-1836. 10.1001/jama.2020.6019

17. Bavishi C, Maddox TM, Messerli FH: Coronavirus disease 2019 (COVID-19) infection and renin angiotensin system blockers (Epub ahead of print). JAMA Cardiol. 2020, 10.1001/jamacardio.2020.1282

18. Xu Z, Shi L, Wang Y, et al.: Pathological findings of COVID-19 associated with acute respiratory distress syndrome. Lancet Respir Med. 2020, 8:420-422. 10.1016/S2213-2600(20)30076-X

19. Hanley B, Lucas SB, Youd E, Swift B, Osborn M: Autopsy in suspected COVID-19 cases. J Clin Pathol. 2020, 73:239-242. 10.1136/jclinpath-2020-206522

20. Cheng SC, Chang YC, Fan Chiang YL, et al.: First case of coronavirus disease 2019 (COVID-19) pneumonia in Taiwan. J Formos Med Assoc. 2020, 119:747-751. 10.1016/j.jfma.2020.02.007

21. Silverstein WK, Stroud L, Cleghorn GE, Leis JA: First imported case of 2019 novel coronavirus in Canada, presenting as mild pneumonia. Lancet. 2020, 395:734. 10.1016/S0140-6736(20)30370-6

22. Wang Z, Chen X, Lu Y, Chen F, Zhang W: Clinical characteristics and therapeutic procedure for four cases with 2019 novel coronavirus pneumonia receiving combined Chinese and Western medicine treatment. Biosci Trends. 2020, 14:64-68. 10.5582/bst.2020.01030

23. Lim J, Jeon S, Shin HY, et al.: Case of the index patient who caused tertiary transmission of covid-19 infection in Korea: the application of lopinavir/ritonavir for the treatment of COVID-19 infected pneumonia monitored by quantitative RT-PCR. J Korean Med Sci. 2020, 35:e79. 10.3346/jkms.2020.35.e79

24. Fang Y, Zhang H, Xu Y, Xie J, Pang P, Ji W: CT manifestations of two cases of 2019 novel coronavirus (2019nCoV) pneumonia. Radiology. 2020, 295:208-209. 10.1148/radiol.2020200280

25. Zhang W: Imaging changes in severe COVID-19 pneumonia . Intensive Care Med. 2020, 46:583-585. 10.1007/s00134-020-05976-w

26. Wei J, Xu H, Xiong J, et al.: 2019 novel coronavirus (COVID-19) pneumonia: serial computed tomography findings. Korean J Radiol. 2020, 21:501-504. 10.3348/kjr.2020.0112

27. Duan YN, Qin J: Pre- and posttreatment chest CT findings: 2019 novel coronavirus (2019-nCoV) pneumonia. Radiology. 2020, 295:21. 10.1148/radiol.2020200323

28. Liu P, Tan XZ: 2019 novel coronavirus (2019-nCoV) pneumonia . Radiology. 2020, 295:19. 10.1148/radiol.2020200257

29. Bai HX, Hsieh B, Xiong Z, et al.: Performance of radiologists in differentiating COVID-19 from viral pneumonia on chest ct (Epub ahead of print). Radiology. 2020, 10.1148/radiol.2020200823

30. Guan WJ, Ni ZY, Hu Y, et al.: Clinical characteristics of coronavirus disease 2019 in China . N Engl J Med. 2020, 382:1708-1720. 10.1056/NEJMoa2002032

31. Ai T, Yang Z, Hou H, et al.: Correlation of chest CT and RT-PCR testing in coronavirus disease 2019 (COVID-19) in China: a report of 1014 cases (Epub ahead of print). Radiology. 2020, 10.1148/radiol.2020200642

32. Gandhi RT, Lynch JB, Del Rio C: Mild or moderate Covid-19 (Epub ahead of print) . N Engl J Med. 2020, 10.1056/NEJMcp2009249

33. Shi H, Han X, Zheng C: Evolution of CT manifestations in a patient recovered from 2019 novel coronavirus (2019-nCoV) pneumonia in Wuhan, China. Radiology. 2020, 295:20. 10.1148/radiol.2020200269

34. Lei J, Li J, Li X, Qi X: CT imaging of the 2019 novel coronavirus (2019-nCoV) pneumonia . Radiology. 2020, 295:18. 10.1148/radiol.2020200236

35. Huang C, Wang Y, Li X, et al.: Clinical features of patients infected with 2019 novel coronavirus in Wuhan, China. Lancet. 2020, 395:497-506. 10.1016/S0140-6736(20)30183-5

36. Kalil AC: Treating COVID-19-off-label drug use, compassionate use, and randomized clinical trials during pandemics [Epub ahead of print]. JAMA. 2020, 323:1897-1898. 10.1001/jama.2020.4742

37. Coronavirus disease 2019 (COVID-19) treatment guidelines. (2020). Accessed: May 5, 2020: https://www.covid19treatmentguidelines.nih.gov/.

38. Wang M, Cao R, Zhang L, et al.: Remdesivir and chloroquine effectively inhibit the recently emerged novel coronavirus (2019-nCoV) in vitro. Cell Res. 2020, 30:269-271. 10.1038/s41422-020-0282-0

39. Al-Tawfiq JA, Al-Homoud AH, Memish ZA: Remdesivir as a possible therapeutic option for the COVID-19 . Travel Med Infect Dis. 2020, 34:101615. 10.1016/j.tmaid.2020.101615

40. Martinez MA: Compounds with therapeutic potential against novel respiratory 2019 coronavirus . Antimicrob Agents Chemother. 2020, 64:e00399-e00420. 10.1128/AAC.00399-20

41. Baksh M, Ravat V, Zaidi A, Patel RS: A systematic review of cases of acute respiratory distress syndrome in the coronavirus disease 2019 pandemic. Cureus. 2020, 12:e8188. 10.7759/cureus.8188

42. NIH clinical trial shows remdesivir accelerates recovery from advanced COVID-19 . (2020). Accessed: May 9, 2020: https://www.nih.gov/news-events/news-releases/nih-clinical-trial-shows-remdesivir-acceleratesrecovery-advanced-covid-19.

43. Coronavirus (COVID-19) update: FDA issues emergency use authorization for potential COVID-19 treatment. (2020). Accessed: May 6, 2020: https://www.fda.gov/news-events/pressannouncements/coronavirus-covid-19-update-fda-issues-emergency-use-authorizatio.... 